Meta

Journal des tradlucteurs

Translators' Journal

\title{
Conseils pour le choix d'un traducteur
}

\section{La rédaction}

Volume 17, numéro 2, juin 1972

URI : https://id.erudit.org/iderudit/003920ar

DOI : https://doi.org/10.7202/003920ar

Aller au sommaire du numéro

Éditeur(s)

Les Presses de l'Université de Montréal

\section{ISSN}

0026-0452 (imprimé)

1492-1421 (numérique)

Découvrir la revue

Citer cet article

La rédaction (1972). Conseils pour le choix d'un traducteur. Meta, 17(2),

119-120. https://doi.org/10.7202/003920ar d'utilisation que vous pouvez consulter en ligne.

https://apropos.erudit.org/fr/usagers/politique-dutilisation/ 
CONSEILS POUR LE CHOIX DUN TRADUCTEUR

Les lignes qui suivent sont extraites d'une lettre adressée par le président d'une société canadienne au président d'une autre firme afin de l'aider à se choisir de bons traducteurs. Nous avons estimé que ces pensées seraient utiles aux lecteurs de Meta.

«Most translators, and the bulk of the best ones, are women, even for technical things. A man technical translator should have at least one Doctorate degree. $\gg$

1. W. M. Crouse, Automotive Mechanics, 6e éd., New York, MacGraw-Hill Book Company, 1970 , p. $249-254$. 
«Things that are even slightly technical require a technical translator and most translators fall into this class. 》

«Most good translators-interpreters are graduates of the Sorbonne School of Languages (even for German translations), but there are some other good ones. 》

«I would not hire a French-Canadian or French-Canadian firm to do translations from Parisian French.

"We have a private secretary who is of Scottish and Italian parentage, has a secondary School education plus three winters of night classes in French. I have just checked with her and she confirms that single-page, single-spaced letters translated French-English or English-French by her take from between twenty and thirty minutes, longer letters about the same time per page. The letters I give her to translate have the normal amount of technical content for the [...] industry. Conseils donnés le plus sérieusement du monde, bien sûr.

LA RÉDACTION 